\title{
Potential and Rainfed Yield Gap for Maize Hybrid NK-6240 under Current Climate of North Interior Karnataka: DSSAT Model based Assessment
}

\author{
B. V. Nargal and R. H. Patil* \\ Department of Agricultural Meteorology, University of Agricultural Sciences, \\ Dharwad, Karnataka, India \\ *Corresponding author
}

\section{Keywords \\ DSSAT, Maize, \\ Potential yield, \\ Rainfed yield, Yield \\ gap}

Article Info

Accepted:

16 November 2020

Available Online:

10 December 2020

\section{A B S T R A C T}

In north interior Karnataka (NIK) maize is the major crop grown during kharif season and NK-6240 is a promising private hybrid used by farmers of this region. However, more often farmers fail to harvest potential yield. The yield gap analysis is very essential to quantify the difference between potential yield and actual yield of a given crop so that adaptations are devised to fill the gap. This plays very important role especially for the crops grown under rainfed conditions because the yield is limited more often by water stress followed by $\mathrm{N}$ stress in the rainfed conditions. Therefore, it is required to quantify the yield gap between potential and actual yield under rainfed conditions so that crop management strategies are developed to fill the gap. For this calibrated and validated DSSAT-CERES model was used to run seasonal analysis from 1988 to 2018 (31 years) for the maize hybrid NK-6240 under potential (no water stress) and rainfed conditions on black and red soils across 12 districts of NIK. Among the 12 districts on the black soil, the highest yield gap was simulated for Koppal district $(63.5 \%)$ and the least was for Belagavi district $(0.0 \%)$ whereas, on red soils the highest gap was simulated for Koppal district $(55.2 \%)$ and the least was for Haveri district $(6.2 \%)$. The simulated results showed that the average grain yield across soils and districts in rainfed conditions for NIK was $6906 \mathrm{~kg}$ $\mathrm{ha}^{-1}$ and when the crop was grown on moisture stress free conditions the yield improved on average for whole of NIK by 19.9 per cent at $8278 \mathrm{~kg} \mathrm{ha}^{-1}$ indicating that there is a scope to improve grain yield of maize in NIK by growing the crop under potential conditions compared to rainfed.

\section{Introduction}

Maize (Zea mays L.), a member of the grass family Poaceae, is a cereal grain crop was first cultivated in ancient Central America. Currently, maize is grown globally on an area of $192.45 \mathrm{~m}$ ha producing $1,113 \mathrm{~m} \mathrm{t}$ at a productivity of $5.7 \mathrm{t} / \mathrm{ha}(2019-20)$. The USA produces more than 32 per cent of the global maize output whereas, China, Brazil, Argentina, Bolivia and India are the other major countries. India accounts for 2.5 per cent of the world's total production. In India during 2019-20 it was grown on an area of 9.2 $\mathrm{m}$ ha producing $28.90 \mathrm{~m} \mathrm{t}$ with a productivity of $3.12 \mathrm{t} / \mathrm{ha}$ of which 72 per cent is grown in Kharif and 28 per cent during Rabi (Anon., 2020). Karnataka is the top producer of maize 
in India contributing 14 per cent of India's total maize production, followed by Maharashtra and Madhya Pradesh (Anon., 2019).

The importance of the rainfed agriculture can be gauged from the fact that it contributes to 40 per cent of the country's food production and accounts for majority of national acreage under coarse cereals $(85 \%)$, pulses $(83 \%)$, oilseeds $(70 \%)$ and holds 60 per cent of the total livestock populations (Venkateswarlu and Prasad 2012). Quantifying the yield potential of maize at any given location is very important to understand the existing yield gaps and to identify the most important constraints in achieving optimal yield. Understanding the causes of these yield gaps allows scientists to prioritize their efforts in improving yield and help farmers fill the gaps in a sustainable and environmentally sound fashion (Mohanty et al., 2017).

However, quantifying the yields at different production and management levels through field experiments involves many years of data collection to find solutions, and field experiments also by nature, workout time consuming and expensive. Hence, for such type of studies process based dynamic crop simulation models are developed which predict crop growth, development and yield using systems approach by integrating underlying bio-physical processes, (Boote et al., 1996). Such models are increasingly used in the yield gap analysis by assessing the water non-limiting and limiting yields or nutrient-limiting and non-limiting yields for a given region and environmental conditions that characterize the factors to define crop growth and development (Aggarwal and Kalra, 1994; Lansigan et al., 1996; Naab et al., 2004).

Jones and Kiniry back in 1986 reported that CERES-Maize model was one of the most widely used models among the number of maize models that existed. Since then DSSAT-CERES maize has been used quite extensively across the world (White et al., 2011; Patil, R. H., 2019). The latest version DSSAT 4.7 was released in April 2019 and is a dynamic model that estimates the timing of different phenological stages of the crop growth rate and the partitioning of biomass to growing organs (roots, stem, leaves, and kernels) with a daily time step as the model simulates crop responses to changes in climate, management variables and soils.

In this study an attempt has been made to quantify the yield gap in maize hybrid NK6240 between rainfed and potential (water non-limited) conditions across 12 districts of north interior Karnataka using CERES-Maize model with a hypothesis that potential yields will be much higher than rainfed yields, and also the gap between the two varies among the districts of NIK based on climate and soil.

\section{Materials and Methods}

\section{Source of input data for modeling}

The experimental crop data of maize hybrid NK-6240 to calibrate and validate crop simulation model were collected from the AICRP- Maize scheme experiments carried out during Kharif season of 2017-18 and 2018-19 under both rainfed and irrigated condition on deep black soils at Main Agricultural Research Station (MARS) of University of Agricultural Sciences, Dharwad, located at $15^{\circ} 26^{\prime} \mathrm{N}$ latitude, $75^{\circ} 07^{\prime} \mathrm{E}$ longitude and at an altitude of $678 \mathrm{~m}$ above mean sea level.

The crop data on daily weather parameters such as rainfall $(\mathrm{mm})$, mean maximum and minimum temperature $\left({ }^{\circ} \mathrm{C}\right)$ and solar radiation $\left(\mathrm{MJ} \mathrm{m}^{-2}\right.$ day $^{-1}$ ) required to build weather file within the DSSAT model were recorded 
fromthe Meteorological Observatory, Main Agricultural Research Station, University of Agricultural Sciences, Dharwad for the experimental years 2017-18 and 2018-19. Historic weather of 31 years from 1988 to 2018 for each of 12 districts of NIK were downloaded from NASA power web portal (www.power.larc.nasa.gov) for subsequent seasonal analysis. Yearly weather files of 2017-18 and 2018-19for Dharwad where experiments were carried out as well as one combined file for the whole period of 19882018 (31 years) for each of 12 districts were built using Weather Man software within the DSSAT ensemble. These files were used to run the model for calibration (2017-18) followed by validation (2018-19) and also for sequential analysis for 31 years (1988-2018) to estimate yield. The soil module within DSSAT model requires data / information on texture, colour, slope (\%), nutrients like N, P, $\mathrm{K}\left(\mathrm{kg} \mathrm{ha}{ }^{-1}\right), \mathrm{pH}$, OC (\%) and BD $\left(\mathrm{g} \mathrm{cm}^{-3}\right)$ across depth. The experiment from which the crop data collected were laid out on black clay soil, hence composite soil samples were collected before the start of experiment and analyzed. In order to simulate the yield levels across the 12 districts of NIK, soil profile data of two predominant soil types i.e., black and red soils up to depth of $125 \mathrm{~cm}$ and $35 \mathrm{~cm}$, respectively, of all these 12 districts were collected from ICAR Krishi Geoportal website (http://geoportal.icar.gov.in).

The N, P, K $\left(\mathrm{kg} \mathrm{ha}^{-1}\right)$ data of all the 12 districts for initial management was collected from soil health card web portal of the Ministry of Agriculture and Farmers Welfare, Govt. of India (https:soilhealth2.dac. gov.in/Health Card). The model was calibrated using 2017-18 experimental data and was validated using 2018-19 experimental data for the maize hybrid NK6240 using GenCalc software embedded within DSSAT model with a satisfactory accuracy of 90 per cent for both phenology and yield parameters and the genetic coefficients optimized for NK-6240 are presented in Table 1.

The seasonal analysis simulations were ran for each of 12 districts of NIK both under rainfed and potential conditions across eight different dates of sowing at weekly interval from $22^{\text {nd }}$ May to $15^{\text {th }}$ July on two predominant representative black and red soils using district level historic weather data of 31 years (1988-2018) to generate average yields of maize hybrid NK-6240 for each district seperately under rainfed and potential conditions grown. In the present study, yield gap was estimated from the difference between rainfed yield (water limited) and potential yield (no water limited) of maize on both black and red soils for each district for current climate.

\section{Results and Discussion}

Considerable difference in yield was simulated between rainfed and potential conditions both on black and red soils across districts and between soils as well as among districts. Simulated grain yieldof maize hybrid NK-6240 under current climate (19882018) on black soils in rainfed conditions was the highest in Bidar (8416 $\left.\mathrm{kg} \mathrm{ha}^{-1}\right)$, closely followed by Dharwad (8319 $\left.\mathrm{kg} \mathrm{ha}^{-1}\right)$ and Bagalakote (8309 kg ha ${ }^{-1}$ ) districts whereas, the lowest yield was simulated in Koppal (4737 $\mathrm{kg} \mathrm{ha}^{-1}$ ) followed by Raichur $(6035 \mathrm{~kg}$ $\mathrm{ha}^{-1}$ ) and Ballari (6099 $\left.\mathrm{kg} \mathrm{ha}^{-1}\right)$ districts among the 12 districts of NIK. When the moisture limitation of rainfed condition was overcome by providing irrigation as and when crop required (potential conditions), the yield levels improved up to 63.5 per cent (for Koppal) compared to rainfed conditions. The simulated grain yield under current climate on black soils in potential conditions was the highest in Gadag (9505 $\left.\mathrm{kg} \mathrm{ha}^{-1}\right)$, followed by Vijayapura (9126 kg ha ${ }^{-1}$ ) and Bagalakote 
$\left(9088 \mathrm{~kg} \mathrm{ha}^{-1}\right)$ districts, and the lowest yield was recorded for Belagavi (6591 $\mathrm{kg} \mathrm{ha}^{-1}$ ) followed by Haveri (7096 $\left.\mathrm{kg} \mathrm{ha}^{-1}\right)$ and Koppal $\left(7744 \mathrm{~kg} \mathrm{ha}^{-1}\right)$ districts among the 12 districts of NIK. Belagavi district however didn't show any improvement under potential conditions. Some 17.8 per cent yield improvement averaged across 12 districts of NIK was simulated when the crop was grown under potential conditions than under rainfed conditions on black soils (Fig.1 and Table 2).

Table.1 Codes description and genetic coefficients used in genotype file of DSSAT for maize hybrid NK-6240

\begin{tabular}{|c|c|c|c|}
\hline Sl. No. & $\begin{array}{l}\text { Coefficient } \\
\text { code }\end{array}$ & Description & $\begin{array}{l}\text { Optimized } \\
\text { values }\end{array}$ \\
\hline 1 & P1 & $\begin{array}{l}\text { Thermal time from seedling emergence to the end of the } \\
\text { juvenile phase (expressed in degree days above a base } \\
\text { temperature of } 8^{\circ} \mathrm{C} \text { ) during which the plant is not responsive } \\
\text { to changes in photoperiod. }\end{array}$ & 221.5 \\
\hline 2 & $\mathrm{P} 2$ & $\begin{array}{l}\text { Extent to which development (expressed as days) is delayed } \\
\text { for each hour increase in photoperiod above the longest } \\
\text { photoperiod at which development proceeds at a maximum } \\
\text { rate (which is considered to be } 12.5 \text { hours). }\end{array}$ & 0.0860 \\
\hline 3 & P5 & $\begin{array}{l}\text { Thermal time from silking to physiological maturity } \\
\text { (expressed in degree days above a base temperature of } 8^{\circ} \mathrm{C} \text { ) }\end{array}$ & 1014 \\
\hline 4 & G2 & Maximum possible number of kernels per plant. & 195.8 \\
\hline 5 & G3 & $\begin{array}{l}\text { Kernel filling rate during the linear grain filling stage and } \\
\text { under optimum conditions ( } \mathrm{mg} / \text { day). }\end{array}$ & 20.64 \\
\hline 6 & PHINT & $\begin{array}{l}\text { Phylochron interval; the interval in thermal time (degree } \\
\text { days) between successive leaf tip appearances. }\end{array}$ & 28.83 \\
\hline
\end{tabular}

Table.2 Simulated average actual yield, potential yield and yield gap between the two for maize hybrid NK-6240 under current climate (1988-2018) on both black and red soils for each of 12 districts of NIK (Values presented are the average of 31 years)

\begin{tabular}{|l|c|c|c|c|c|c|c|c|}
\hline \multirow{2}{*}{ Districts } & \multicolumn{9}{|c|}{ Black soils } & \multicolumn{3}{c|}{ Red soils } \\
\cline { 2 - 10 } & $\begin{array}{c}\text { Rainfed } \\
(\mathbf{A})\end{array}$ & $\begin{array}{c}\text { Potential } \\
(\mathbf{B})\end{array}$ & $\begin{array}{c}\text { B-A } \\
(\mathbf{\%})\end{array}$ & Ranking & $\begin{array}{c}\text { Rainfed } \\
(\mathbf{A})\end{array}$ & $\begin{array}{c}\text { Potential } \\
(\mathbf{B})\end{array}$ & $\begin{array}{c}\text { B-A } \\
(\boldsymbol{\%})\end{array}$ & Ranking \\
\hline Bagalakote & 8309 & 9088 & 9.0 & VIII & 7385 & 8830 & 20.0 & VI \\
\hline Ballari & 6099 & 8749 & 43.5 & II & 5464 & 7885 & 44.3 & II \\
\hline Belagavi & 6592 & 6592 & 0.0 & XII & 7735 & 8225 & 6.3 & XI \\
\hline Bidar & 8416 & 8743 & 3.9 & X & 7716 & 8240 & 6.8 & X \\
\hline Dharwad & 8319 & 8689 & 4.4 & IX & 7424 & 8787 & 18.4 & VIII \\
\hline Gadag & 7996 & 9505 & 18.9 & VI & 7050 & 8375 & 18.8 & VII \\
\hline Haveri & 7080 & 7096 & 0.2 & XI & 7575 & 8043 & 6.2 & XII \\
\hline Kalaburgi & 8139 & 8966 & 10.2 & VII & 6815 & 7906 & 16.0 & IX \\
\hline Koppal & 4737 & 7744 & 63.5 & I & 5018 & 7786 & 55.2 & I \\
\hline Raichur & 6035 & 8094 & 34.1 & III & 5873 & 7717 & 31.4 & IV \\
\hline Vijayapura & 6931 & 9126 & 32.0 & IV & 6139 & 8495 & 38.0 & III \\
\hline Yadagiri & 6875 & 8335 & 21.6 & V & 6029 & 7674 & 27.3 & V \\
\hline
\end{tabular}

$\mathrm{B}-\mathrm{A}=$ per cent difference in yield between potential and rainfed crop 
Table.3 Simulated average actual yield, potential yield and yield gap between the two for maize hybrid NK-6240 under current climate (1988-2018) on both black and red soils averaged for 12 districts of NIK and eight dates of sowing over 31 years (values in the parenthesis indicate \pm S.E with $\mathrm{n}=2976$ )

\begin{tabular}{|c|c|c|c|}
\hline \multirow{2}{*}{ Soil } & \multicolumn{2}{|c|}{$\mathbf{1 9 8 8 - 2 0 1 8}$} & \% difference \\
\cline { 2 - 4 } & Potential (B) & Rainfed (A) & B-A \\
\hline Black & $8393( \pm 248)$ & $7126( \pm 412)$ & $17.8 \%$ \\
\hline Red & $8164( \pm 117)$ & $6685( \pm 277)$ & $22.1 \%$ \\
\hline Average & $8278( \pm 182)$ & $6906( \pm 344)$ & $19.9 \%$ \\
\hline
\end{tabular}

Fig.1 Simulated difference (c) in grain yield (\%) of maize hybrid NK-6240 between rainfed (a) and potential (b) conditions $\left(\mathrm{kg} \mathrm{ha}^{-1}\right)$ under current climate (1988-2018) on black and red soils across 12 districts of NIK (average of 31 years)

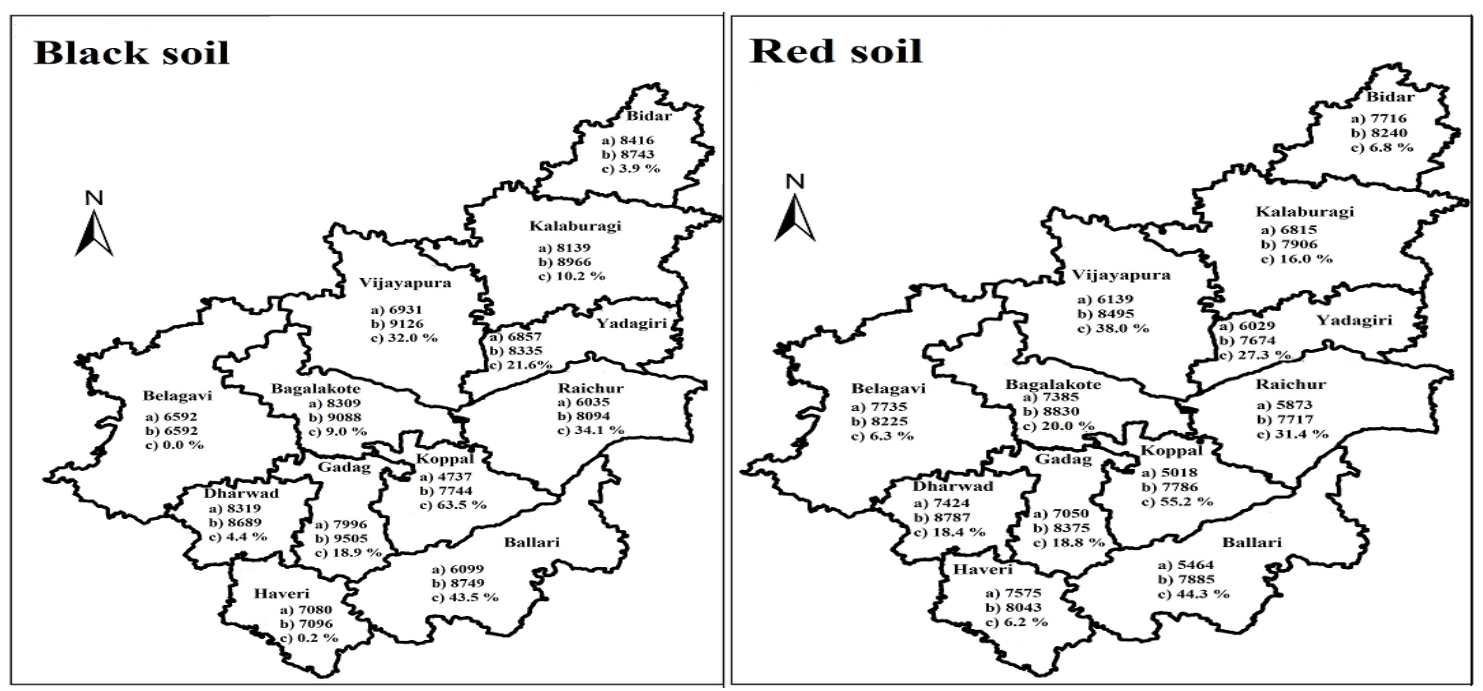

Fig.2 Rainfed and potential yield of maize hybrid NK-6240 under current climate (1988- 2018) on black and red soils averaged across 12 districts of NIK and eight dates of sowing

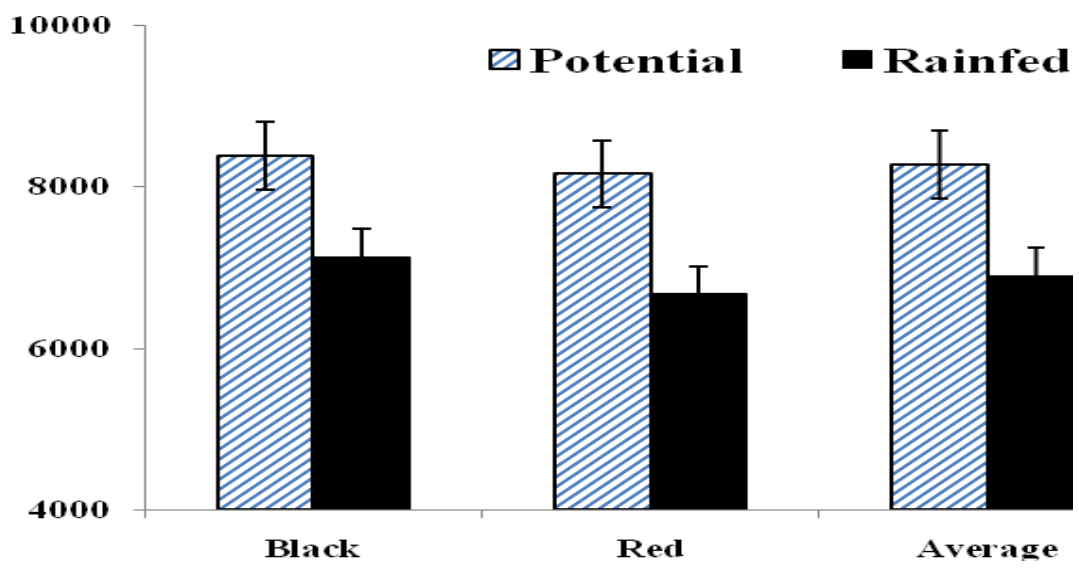


With respect to red soil, among 12 districts of NIK, the highest grain yield under current climate in rainfed conditions was simulated for Belagavi (7735 kg ha ${ }^{-1}$ ) followed by Bidar (7716 kg ha ${ }^{-1}$ ) and Haveri (7575 $\mathrm{kg} \mathrm{ha}^{-1}$ ) districts, and the lowest yield was simulated for Koppal (5018 $\mathrm{kg} \mathrm{ha}^{-1}$ ), followed by Ballari (5464 $\mathrm{kg} \mathrm{ha}^{-1}$ ) and Raichur (5873 kg ha-1) districts. On an average across NIK 6.2 per cent lesser yield was simulated on red soil and dates of sowing compared to black soil. When the moisture limitation of rainfed condition was overcome by providing irrigation as and when crop required (potential conditions), the yield levels improved anywhere between 6.2(for Haveri district) and 55.2 per cent (for Koppal district) compared to rainfed conditions. Under potential conditions grain yield in current climate on red soils was the highest in Bidar $\left(8830 \mathrm{~kg} \mathrm{ha}^{-1}\right)$, followed by Dharwad $\left(8787 \mathrm{~kg} \mathrm{ha}^{-1}\right)$ and Vijayapura (8495 $\mathrm{kg} \mathrm{ha}{ }^{-1}$ ) districts and the lowest yield was simulated in Yadagiri (7674 $\left.\mathrm{kg} \mathrm{ha}^{-1}\right)$, followed by Raichur (7717 $\mathrm{kg} \mathrm{ha}^{-1}$ ) and Koppal (7786 kg ha ${ }^{-1}$ ) districts among 12 districts of NIK. On an average across 12 districts of NIK and dates of sowing 22.1 per cent yield improvement on red soil was simulated when the crop was grown in potential conditions than under rainfed conditions (Fig. 1 and Table 2). Response in yield to irrigation was higher in red soils (22.1 $\%)$ than on black soil (17.8\%). Grain yield averaged across both the soils of 12 districts in rainfed conditions was $6906 \mathrm{~kg} \mathrm{ha}^{-1}$ and when the crop was grown on moisture stress free conditions the yield improved, on average, by 19.9 per cent at $8278 \mathrm{~kg} \mathrm{ha}^{-1}$ (Table 3 and Fig. 2).

In conclusion the analysis of yield gap using the DSSAT 4.7 CERES-Maize model for NIK allowed to quantitatively understand the magnitude of yield gap under rainfed and potential conditions for each district on both black and red soil. This study indicated that there is a scope to improve grain yield of maize, on average, by 19.9 per cent in NIK by growing the crop under water non-limiting conditions compared to rainfed. Especially Koppal, Ballari and Raichur districts on black soil and Koppal, Ballari and Vijayapura districts on red soils as these districts showed the highest yield gap between rainfed and water non-limiting potential conditions.

\section{References}

Achenef, T. B., 2017, Response of maize hybrids to increasing $\mathrm{CO}_{2}$ and temperature scenarios: DSSAT model based assessment for Northern Transition Zone of Karnataka. Ph. D (Agri.) Thesis., University of Agricultural Sciences., Dharwad. pp. 338.

Achenef, T. B. and Patil. R. H., 2018, Response of maize hybrids to sowing dates in Northern Transition Zone of Karnataka. Intl. J. of Pure App. Biosci., 6(1):71-84.

Aggarwal, P. K. and Kalra, N., 1994, Simulating the effect of climatic factors, genotype, water and nitrogen availability on productivity of wheat: II. Climatically potential yields and optimal management strategies. Field Crop Res., 38: 93-103.

Anonymous, 2019, Directorate of Economics and Statistics. Department of Agriculture and Cooperation Report, New Delhi. pp. 66.

Anonymous, 2020, United States Department of Agriculture, World Agricultural Production. pp. 23. (https://www.fas. usda.gov/data/world-agriculturalproduction).

Boote, K.J., Jones, J. W. and Pickering, N. B., 1996, Potential uses and limitations of crop models. Agron. J., 88: 704-716.

Chaturvedi, R., Joshi, J., Jayaraman, M.,Bala, G. and Ravindranath, N. H. 2012, 
Multi-model climate change projections for India under representative concentration path ways.Cur.Sci., vol. 103, no. 7.

Jones, C. A., Kiniry, J. R., and Dyke, P. T. (1986). CERES-Maize: A simulation model of maize growth and development. College Station: Texas A \& $M$ University Press.

Lansigan, F.P., Bouman, B.A.M., Aggarwal, P. K., Thiyagarajan, T. M. andRubia, E. G., 1996, Yield gaps in selected riceproducing areas in the Philippines; SAARP Research Proceedings, Wageningen and Los Bafios, pp. 11-18.

Mohanty, M., Sinha, K., Patidar, R., Somasundaram, J., Chaudhary, R. S., Hati, K. M., Sammi K., Prabhakar, M., Cherukumalli, S. and Ashok,K. P., 2017, Assessment of maize (Zea mays L.) productivity and yield gap analysis using simulation modelling in subtropical climate of central India.J. Agromet. 19 (4): 342-345.

Naab, J.B., Singh, P., Boote, K.J., Jones, J. W. and Marfo, K. O., 2004, Using CROPGRO-Peanut model to quantify yield gaps in the Guinean Savanna zone of Ghana. Agron. J., 96: 1231-1242.

Patil, R. H., 2019, Applications of crop simulation models in global agriculture research: A review. J. Farm Sci., 32(4): (377-387).

Pradeep, M. G., 2017, Performance of maize hybrids for the current and rising temperature scenarios: DSSAT model based assessment. M. Sc. (Agri.) Thesis., University of Agricultural Sciences, Dharwad. pp. 127.

Pradeep, M. G. and Patil, R. H., 2017, Response of public maize hybrids to global warming and adaption stratagies: DSSAT Model based assessment. $J$. Agric. Res. Technol., 42 (3):44-47.

Pradeep, M. G. and Patil, R. H., 2017, Evaluation of maize hybrids for their maturity groups and their effect on yield.Int.J. Pure App. Biosci. 6 (3): 382387.

Pradeep, M. G. and Patil, R. H., 2019, Yield variability of maize hybrids to climate change in northen karnataka: DSSAT model analysis. J. Agric. Res. Technol., 44 (1):20-25.

Pradeep, M. G. and Patil, R. H., 2019, Evaluation of private and public maize hybrids for their potential yield under northern transition zone of Karnataka, India. Int. J. Curr. Microbiol. App. Sci. 7(1): 3565-3571.

Venkateswarlu, B. and Prasad, JVNS. 2012, Carrying Capacity of Indian Agriculture: Issues Related to Rainfed Farming. Cur. Sci. 102(6): 882-8.

White, J. W., Hoogenboom, G., Kimball, B. A. and Wall, G. W., 2011, Methodologies for simulating impacts of climate change on crop production. Field. Crop. Res., 124: 357-368.

\section{How to cite this article:}

Nargal, B. V. and Patil, R. H. 2020. Potential and Rainfed Yield Gap for Maize Hybrid NK6240 under Current Climate of North Interior Karnataka: DSSAT Model based Assessment. Int.J.Curr.Microbiol.App.Sci. 9(12): 2245-2251. doi: https://doi.org/10.20546/ijcmas.2020.912.265 